\title{
AN EXPERIMENTAL STUDY ON JOINT STRENGTH OF SPLICED BARS USING SPIRAL SHEATHS FOR PRECAST CONCRETE STRUCTURES
}

\author{
シースを用いたプレキャストコンクリート構造用の \\ 重ね継手の継手強度に関する実験的研究 \\ Rodolfo YANEZ*, Juan Jose CASTRO**, Teruaki YAMAGUCHI *** \\ and Hiroshi IMAI**** \\ ジャニエス ロドルフォ, カストロ ホワン ホセ \\ 山口輝彰, 今井弘
}

\begin{abstract}
An experimental investigation was carried out to study the joint strength of lapping splices using spiral sheaths for precast concrete members. Two series of pullout tests were carried out. The influence of the height of sheath lug, thickness of cover concrete, lateral reinforcement ratio, lapping length, and loading history on the joint strength of the lapping joints in the first series as well as the influence of the lapping splice type, position of bar inside the sheath and the number of lapping bars on the joint strength in the second series were investigated and discussed using the existing strength equations for lapping splices.
\end{abstract}

Keywords: precast concrete, joint strength, splice type, lapping bars, spiral sheath, mortar

プレキャストコンクリート、継手強度、継手形式、添え筋、シース、モルタル

\section{Introduction}

One of the most important aspects in the design of precast concrete structures is the connection details. Connections between precast members should effectively integrate the individual structural members in full continuity so that the overall building structure behaves monolithically.

In the early days of precasting, different precast systems have been proposed to solve the problems arising in the construction industry of precast concrete structures. One of these precast system is shown in Figure 1(a). It has the feature that the precast concrete members are connected at the middle part of either beams or columns. The connectors used were mechanical bar joints reinforced with steel plates to ensure shear transfer between the precast elements. This system has some disadvantages in prefabricating and transporting of members and also in installing the transverse beams.

Figure 1(b) shows another precast concrete system. In this system the precast concrete members are connected at the beam-column joint which is cast at the site. This system uses the type of beam called "half precast concrete beam" in which the lower main bars and the lateral reinforcement are embedded. At the construction site, after the upper main bars of the beam and the joint reinforcements are placed, the concrete at the beam-column joints and upper part of beams is cast. This system has many advantages compared with the previous one, but the bar joints are placed at the ends of precast concrete members where the stresses due to seismic forces are large.

In the conventional precast concrete methods, the main bars are hitherto contained inside the precast concrete members after casting and jointed at the same place where the precast concrete members are connected. Therefore, it was difficult to develop precast concrete structures with both efficient productivity and high seismic performance.

To fulfill with the standard requirements of AIJ[1], which restricts bar jointing at stressed portions like the

* Researcher, Graduate School, University of Tsukuba, Dr. Eng.

** Senior Research Engineer, Technical Research Institute, Kabuki Construction Co, Ltd., Dr. Eng.

*** Senior Research Engineer, Technical Research Institute, Kabuki Construction Co, Ltd.

**** Assoc. Prof., Institute of Engineering Mechanics, University of Tsukuba. Dr. Eng.
筑波大学 研究員 博士(工学)

株木建設技術研究所 主任研究貣・博士 (工学)

株木建設技術研究所 主任研究員

筑波大学構造工学系 助教授・博士 (工学) 


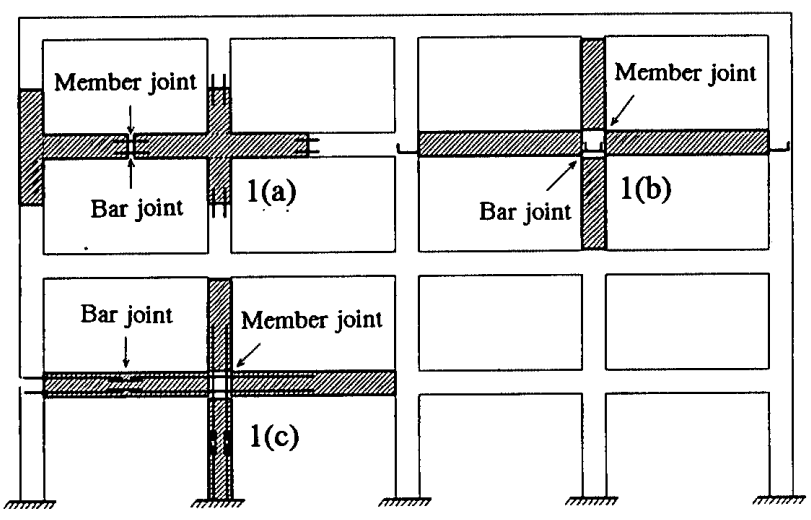

Fig. 1 Different precast concrete systems

hinge zone, a cheaper and simple bar joint method for precast concrete has been developed $[2,3,4]$. The main bars are not placed inside when the precast members are prefabricated and the bar joints are located at the middle part of each member where the stresses due to seismic forces are small, as shown in Figs. 1 (c) and 2. At the position of each main bar, a steel spiral sheath is placed. This sheath is lapped with either two or one bar depending on the following cases: for columns, 2 bars, and for beams, 1 bar. Generally, beams are subjected to unidirectional bending, while columns to bidirectional bending. The length of beams is long enough to allow the splicing of bars with a lapping length longer than those in columns without reaching the hinge region. In the case of two lapping bars, the total sectional area of these lapping bars is equal to or larger than that of the main bar, for one lapping bar, a bar with the same size as the main bar is proposed. At the construction site, the main bars are inserted into the sheaths, passing through the beam-column joints and allowing the end of each bar to abut at the center of each precast concrete member, after which, a high strength mortar is grouted into the sheaths. For the beam bottom bars, long lapping bars are used and considering the stress due to vertical loads, the lapped parts are shifted from the center of beam, as shown in Fig. 2, The transfer mechanism of this lapping joint method is that the stress at one end of main bar is transferred progressively from the mortar to the lapping bars by bond stresses on the sheath and vice versa.

In reinforced concrete members, the bond performance of deformed bars confined by concrete depends mainly on the mechanical interlocking between lugs and concrete. Adhesion and friction between the rough bar surface and concrete add only a little to the bond resistance [5]. The bond characteristic of the proposed precast concrete system (main bar-mortar-sheath-lapping bars) can be supposed also to be primarily governed by the interlocking between lugs of the sheath and the lapping bars and concrete. Also another premise is that, the high strength mortar confined by a steel sheath acts in such a way that no failure will be produced between the interior lugs of the sheath and bar lugs. However, it is a fact that as the bar diameter increases, the resistant surface of concrete to the splitting forces becomes smaller and the bond strength may decrease. Therefore as in the proposed system the sheath diameter (42 $\mathrm{mm}$ ) is larger than that of main bars this may result in smaller bond strength.

The feasibility of this system should be studied by analyzing the bond strength of this lap splicing. This strength should be compared with the existing formulas for predicting bond strength. From all the existing formulas, three were chosen: Fujii-Morita [6], Orangun-Jirsa-Breen

[7] and Jimenez-WhiteGergely [8]. In the study by Fujii and Morita which was made using continuous bars, the ultimate splitting bond strength is a result of

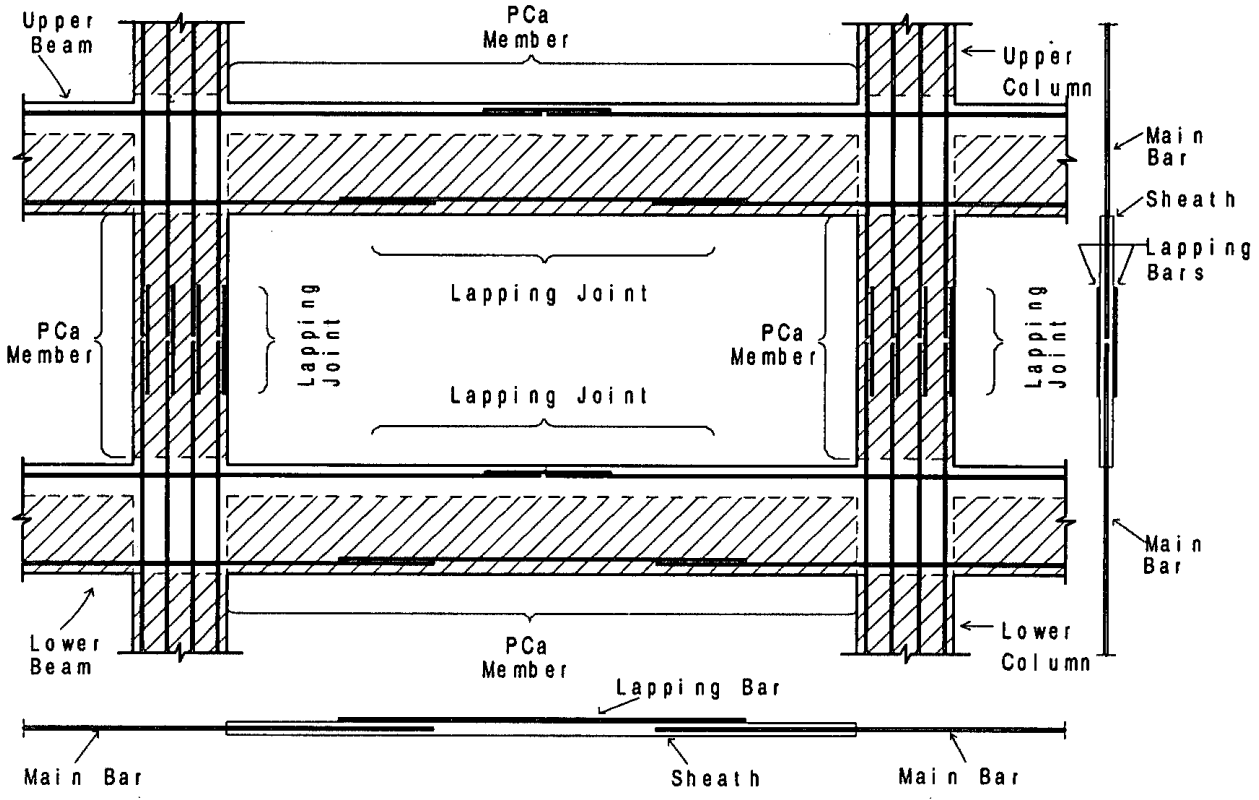

Fig. 2 Proposed system 
the contribution of the concrete matrix and the lateral reinforcement. Orangun, Jirsa and Breen as well as Jimenez, White and Gergely studied the bond strength on spliced bars. In these two formulas, the contributions of concrete matrix and lateral reinforcement are added to the contribution of the splices: The test results are compared to those obtained using these formulas and are discussed in this paper.

\section{Specimens}

The test specimens were designed to represent a confined section of precast concrete columns or beams. Two series of tests were carried out. In the first series, the specimens were divided into four cases according to the following parameters: lug height of the sheath, thickness of cover concrete, amount of lateral reinforcement, and loading history. Figure 3 shows a detailed section of the specimens. The characteristics of specimens are shown in Table 1. The specimens denoted PS20, PH410 and PL40 are actually same specimen, which is the standard specimen, where all the parameters are resumed. Two specimens were made for each parameter with a total of 22 specimens. The specimens have a section of $600 \times 600 \mathrm{~mm}$ except PL20 and PL30 which have sections of $560 \times 560$ and 580 $x$ 580, respectively. The length was $900 \mathrm{~mm}$. The specimens have four bars located at the top and the bottom, respectively, with.a distance among their axes of $150 \mathrm{~mm}$.

To study the influence of the lug height, three different classes of sheath were selected with lug height of 1.5 $\mathrm{mm}, 2 \mathrm{~mm}$ and $3 \mathrm{~mm}$, as shown in Fig. 4. Also, to study the influence of the lateral reinforcement, ratios of 2D10@100, 4-D10@100, 4-D13@1.00 and 4-D16@100 were selected, with pw of $0.24 \%, 0.48 \%, 0.85 \%$ and $1.3 \%$, respectively. In the study of the influence of the cover concrete thickness $20 \mathrm{~mm}, 30 \mathrm{~mm}$ and $40 \mathrm{~mm}$ were selected. The specimens for the influence of the repeated load were similar to the standard specimen.

Table 1 Differences among the specimens of Series 1

\begin{tabular}{|c|c|c|c|c|c|}
\hline Parameter & Specimen & $\begin{array}{l}\text { Height } \\
\text { of lug } \\
(\mathrm{mm})\end{array}$ & $\begin{array}{c}\text { Lateral } \\
\text { reinforcement } \\
\text { (pw \%) }\end{array}$ & $\begin{array}{l}\text { Cover of } \\
\text { concrete } \\
(\mathrm{mm})\end{array}$ & $\begin{array}{l}\text { Lapping } \\
\text { length } \\
\text { (mm) }\end{array}$ \\
\hline $\begin{array}{l}\text { Height of } \\
\text { the lug of } \\
\text { sheath }\end{array}$ & $\begin{array}{l}\text { PS15 } \\
\text { PS20 } \\
\text { PS30 }\end{array}$ & $\begin{array}{l}1.5 \\
2.0 \\
3.0 \\
\end{array}$ & 4-D10 $(0.48 \%)$ & & \multirow{4}{*}{$\begin{array}{l}380 \\
(20 d)\end{array}$} \\
\hline $\begin{array}{l}\text { Lateral } \\
\text { reinf. }\end{array}$ & $\begin{array}{l}\text { PH210 } \\
\text { PH410 } \\
\text { PH413 } \\
\text { PH416 }\end{array}$ & \multirow{3}{*}{2.0} & $\begin{array}{ll}\text { 2-D10 } & (0.24 \%) \\
\text { 4-D10 } & (0.48 \%) \\
\text { 4-D13 } & (0.85 \%) \\
\text { 4-D16 } & (1.30 \%) \\
\end{array}$ & 40 & \\
\hline $\begin{array}{l}\text { Cover of } \\
\text { concrete }\end{array}$ & $\begin{array}{l}\text { PL20 } \\
\text { PL30 } \\
\text { PLA0 } \\
\end{array}$ & & $4-D 10 \quad(0.48 \%)$ & $\begin{array}{l}20 \\
30 \\
40 \\
\end{array}$ & \\
\hline $\begin{array}{l}\text { Loading } \\
\text { history }\end{array}$ & $\begin{array}{l}\text { PR11 } \\
\text { PR13 } \\
\text { PR15 }\end{array}$ & & & 40 & \\
\hline
\end{tabular}
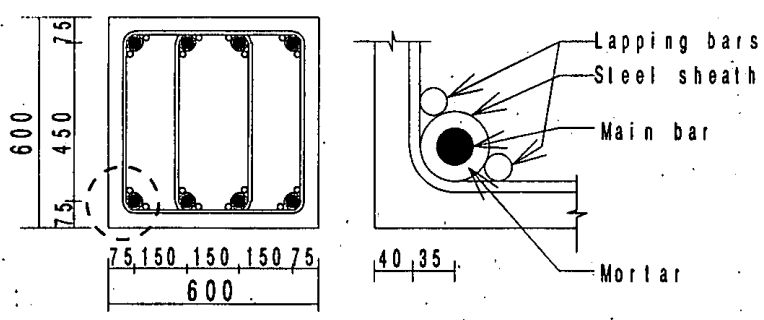

Fig. 3 Section of specimens of Series 1

In the second series, six types of splices were tested.Two types of sections were used: one is a section of $450 \mathrm{~mm} \times 700 \mathrm{~mm}$ with four bars at each side, and the other is a section of $350 \mathrm{~mm} \times 700$ $\mathrm{mm}$ with three bars at each side, as shown in Fig. 5 . In both sections, the distance

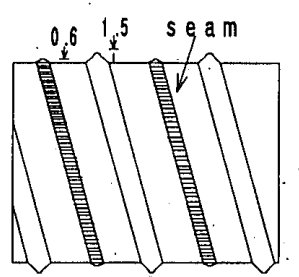

(a) $\mathrm{h}=1.5 \mathrm{~mm} \stackrel{28.0}{\longmapsto}$

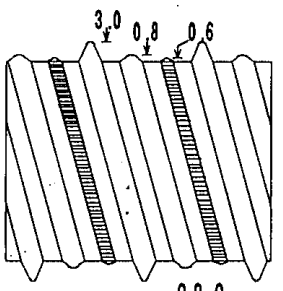

(b) $h=20 \mathrm{~mm} 228.0$

h: nominal lug height

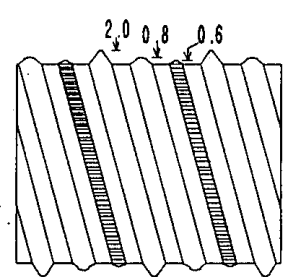

(c) $\mathrm{h}=30 \mathrm{~mm} 28.0$
Fig. 4 Characteristics of the sheath between the bar axes is $100 \mathrm{~mm}$. Differences among the splices are shown in Fig. 6 and listed in Table 2, with two specimens per each case and a total number of 26 specimens. Splice types A and B correspond to those used for precast columns, while $\mathrm{C}$ and $\mathrm{D}$ for precast beams.

It is supposed that at the construction site the bar will lie on the sheath and the bar axis may not coincide with the axis of the sheaths. These cases are represented by splice types B and D. Splice types E, F and G are used commonly for the top bars of beams. Splice types $\mathrm{E}$ and $\mathrm{F}$ were conceived to compare the test results with those of bars with sheaths. Splice type $\mathrm{G}$ is the common bar splice being used up to the present. 
Table 2 Differences among the specimens of Series 2

\begin{tabular}{|c|c|c|c|c|c|c|}
\hline Specimen & $\begin{array}{l}\text { Specimen } \\
\text { length } \\
(\mathrm{mm})\end{array}$ & $\begin{array}{l}\text { Section } \\
(\mathrm{mm})\end{array}$ & $\begin{array}{l}\text { Main } \\
\text { bar }\end{array}$ & $\begin{array}{l}\text { Lapping } \\
\text { bar }\end{array}$ & $\begin{array}{l}\text { Lapping } \\
\text { length } \\
(\mathrm{mm}) \\
\end{array}$ & $\begin{array}{l}\text { Lateral } \\
\text { reinforcement }\end{array}$ \\
\hline $\mathrm{AA}-1$ & \multirow{5}{*}{1000} & \multirow{9}{*}{$450 \times 700$} & \multirow{9}{*}{$4-\mathrm{D} 25$} & \multirow{5}{*}{$2-19$} & \multirow{5}{*}{760} & \multirow[t]{2}{*}{ 4-D10@100 } \\
\hline BB-2 & & & & & & \\
\hline EA-3 & & & & & & 4-D10@150 \\
\hline $\mathrm{EB}-4$ & & & & & & \\
\hline EA-5 & & & & & & 4-D10@200 \\
\hline $\mathrm{CC}-6$ & \multirow{9}{*}{1200} & & & \multirow{4}{*}{$1-\mathrm{D} 25$} & \multirow{4}{*}{1000} & 4-D10@100 \\
\hline FC-7 & & & & & & 4-D10@150 \\
\hline FD-8 & & & & & & \\
\hline FC-9 & & & & & & 4-D10@200 \\
\hline \multirow[t]{2}{*}{$E C-10$} & & \multirow{5}{*}{$350 \times 700$} & \multirow{5}{*}{$3-\mathrm{D} 25$} & 2-D19 & 760 & \multirow[t]{3}{*}{ 2-D10@150 } \\
\hline & & & & $1-\mathrm{D} 25$ & 1000 & \\
\hline DG-11 & & & & \multirow{3}{*}{$1-\mathrm{D} 25$} & \multirow{3}{*}{1000} & \\
\hline FC-12 & & & & & & \multirow[t]{2}{*}{ 3-D10@150 } \\
\hline GD-13 & & & & & & \\
\hline
\end{tabular}
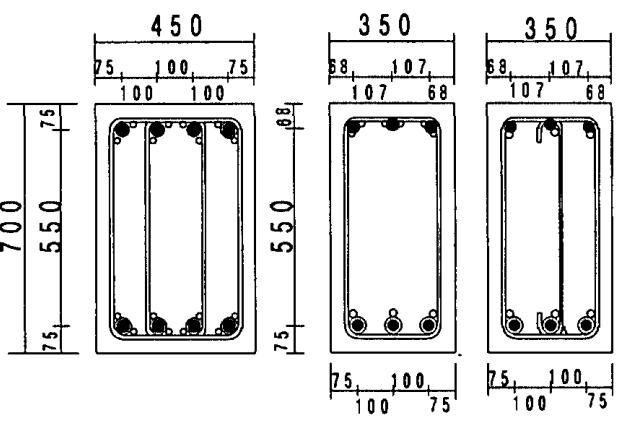

(a) AA-1

(b) EC-10

(c) FC-12

Fig. 5 Section of specimens of Series 2

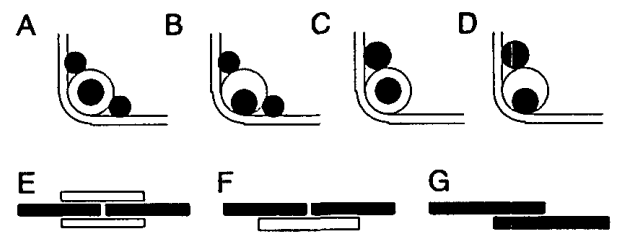

Fig. 6 Type of slices

Table 4 Steel strength properties

(a) Series 1
(a) Series 1
(b) Series (2)

strength for the precast concrete specimens was $\mathrm{Fc}=300 \mathrm{kgf} / \mathrm{cm}^{2}(29.4$ $\mathrm{MPa}$ ) and the specified compressive strength of the grout mortar was $600 \mathrm{kgf} / \mathrm{cm}^{2}(58.8 \mathrm{MPa})$. D25 with specified yield strength of $4000 \mathrm{kgf} / \mathrm{cm}^{2}$ (392 $\mathrm{MPa}, \mathrm{SD} 390$ ) for main bars, and two bars of D19 (SD390) or one bar D25 (SD390) for

\begin{tabular}{|c|c|c|c|c|}
\hline Specimen & $\begin{array}{c}\sigma_{\mathrm{B}} \\
\left(\mathrm{kgf} / \mathrm{cm}^{2}\right)\end{array}$ & \multicolumn{2}{|c|}{ Specimen } & $\begin{array}{c}\sigma_{\text {в }} \\
\left(\mathrm{kgf} / \mathrm{cm}^{2}\right)\end{array}$ \\
\hline PS15 & \multirow{4}{*}{317} & \multirow{2}{*}{$\begin{array}{l}A A-1 \\
F C-9 \\
E C-10\end{array}$} & 1 & 308 \\
\hline $\begin{array}{l}\text { PS20 } \\
\text { PS30 }\end{array}$ & & & 2 & 322 \\
\hline PH413 & & \multirow{3}{*}{$\begin{array}{l}\text { BB-2 } \\
\text { EA-5 } \\
\text { GD-11 }\end{array}$} & 1 & 326 \\
\hline PH416 & & & & \\
\hline $\mathrm{PH} 210$ & \multirow{3}{*}{326} & & 2 & 308 \\
\hline PC20 & & \multirow{3}{*}{$\begin{array}{l}E A-3 \\
C C-6 \\
F C-12 \\
\end{array}$} & 1 & 322 \\
\hline PC30 & & & & \\
\hline PR11 & \multirow{3}{*}{326} & & 2 & 308 \\
\hline PR13 & & \multirow{3}{*}{$\begin{array}{l}\mathrm{EB}-4 \\
\mathrm{FC}-7 \\
\mathrm{GD}-13\end{array}$} & 1 & 305 \\
\hline PR15 & & & & \\
\hline \multirow{2}{*}{\multicolumn{2}{|c|}{$\begin{array}{l}\mathrm{Fc}=300 \mathrm{kgf} / \mathrm{cm}^{2} \\
\sigma_{\mathrm{B}}=\text { Compressive }\end{array}$}} & & 2 & 293 \\
\hline & & FD-8 & 1 & 215 \\
\hline \multicolumn{2}{|c|}{ Strength } & & 2 & 215 \\
\hline
\end{tabular}
lapped bars were chosen for this investigation. Tables 3,4 and 5 show the properties of the materials.

The common parameters for all specimens in both series, except when they were studied, were: a steel spiral sheath of $42 \mathrm{~mm}$ diameter with lug height of $2 \mathrm{~mm}$ and lug spacing of $28 \mathrm{~mm}$, cover concrete of $40 \mathrm{~mm}$ from the surface to the lateral reinforcement, and each specimen had 4-D10 (SD295A) @ 100 as lateral reinforcement. A lapping length which is 20 times the diameter of the lapping bar, 20d, was used for all the specimens.

\begin{tabular}{|l|l|c|c|c|}
\hline Bar & Grade & $\begin{array}{c}\sigma_{\mathrm{y}} \\
\left(\mathrm{tf} / \mathrm{cm}^{2}\right)\end{array}$ & $\begin{array}{c}\sigma_{\mathrm{B}} \\
\left(\mathrm{t} / \mathrm{cm}{ }^{2}\right)\end{array}$ & $\begin{array}{c}\mathrm{E} \\
\left({\left.\mathrm{tf} / \mathrm{cm}^{2}\right)}^{2}\right.\end{array}$ \\
\hline D10 & & 3.8 & 5.1 & 1914 \\
D13 & SD295A & 3.7 & 5.1 & 1835 \\
D16 & & 3.7 & 5.2 & 1919 \\
\hline D19 & SD390 & 4.2 & 6.0 & 1890 \\
D25 & & 4.3 & 6.1 & 1972 \\
\hline
\end{tabular}

(b) Series (2)

\begin{tabular}{|l|l|c|c|c|}
\hline Bar & Grade & $\begin{array}{c}\sigma_{\mathbf{y}} \\
\left(\mathrm{tf} / \mathrm{cm}^{2}\right)\end{array}$ & $\begin{array}{c}\sigma_{\mathrm{B}} \\
\left(\mathrm{tf} / \mathrm{cm}^{2}\right)\end{array}$ & $\begin{array}{c}\text { E } \\
\left(\mathrm{tf} / \mathrm{cm}^{2}\right)\end{array}$ \\
\hline D10 & SD295A & 3.6 & 5.2 & 1930 \\
\hline D19 & SD390 & 4.3 & 6.0 & 1900 \\
D25 & & 4.3 & 6.1 & 1880 \\
\hline
\end{tabular}

Table 5 Grout mortar strength properties

(a) Series 1

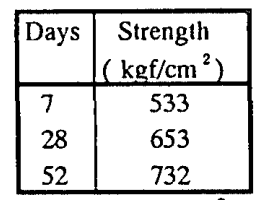

$\mathrm{Fc}=600 \mathrm{kgf} / \mathrm{cm}^{2}$ (b) Series (2)

\begin{tabular}{|c|c|}
\hline Days & $\begin{array}{c}\text { Strength } \\
\left(\mathrm{kgf} / \mathrm{cm}^{2}\right)\end{array}$ \\
\hline 13 & 500 \\
28 & 604 \\
78 & 651 \\
98 & 685 \\
\hline
\end{tabular}

$\mathrm{Fc}=600 \mathrm{kgf} / \mathrm{cm}^{2}$

The concrete of the specimens was cast horizontally. The position of casting was the basis of naming the upper cast bars as "top bars" and the lower cast ones as "bottom bars". The high strength mortar was grouted vertically in the first series. In the second series, concrete blocks were cast in situ at each end of the specimens to seal the sheaths, which correspond to the concrete cast in situ at the beam-column joints. After which mortar was grouted 
horizontally using a pump. There may exist some bond between the testing bars and the concrete blocks, but because there were no steel anchors and the joint surfaces were smooth, an influence of this bond on the joint strength is negligible.

The maximum bond resistance is mainly influenced by the concrete strength, shape of deformed bars, lateral reinforcement ratio, and the position of the bar during casting. The influence of the bar diameter is relatively small if all dimensions (height and distance of bar lugs, and concrete dimensions) are kept constant as multiples of the bar diameters [9]. The steel sheath was selected to have its geometric characteristics similar to those of ordinary reinforcing bars. Those parameters that have influence on the bond resistance of bars are herein discussed for sheaths.

\section{Test Apparatus and Loading History}

The loading arrangements for both series of experiments are shown in Figs. 7(a) and (b). Tension force $P$ was applied horizontally at both ends of each main bar by oil jacks controlled by a load cell. Displacement between the ends of each main bar was also measured. For this purpose, two sets of measuring devices were placed at the corner and side bars as shown in Figure 7(c). Each set consists of four linear voltage displacement transducers (LVDT), two CDP (with an accuracy of $1 / 1000 \mathrm{~mm}$ ) and two SDP (with an accuracy of $1 / 100 \mathrm{~mm}$ ). The displacement of each bar (corner or side) was obtained by extrapolating the measurements of either the CDP or SDP transducers.

To obtain the maximum load, tension force was applied monotonically to all specimens with an increment of 1 tonf until failure. In the case of bottom bars, the maximum load was obtained after the bars yielded or almost yielded. The top bars did not yield before bond failure. Six specimens of the first series were tested under repeated loading.

There is no standard specification on the number of times a steel bar should be subjected to cyclic loading, but Paulay [9] recommended that if the necessary amount of lateral reinforcement is provided to the structural member with lapping splices, these splices must sustain at least 10 cycles of reverse loading. Also because in the standard design requirements the lapping length is at least $30 \mathrm{~d}, 30$ times the lapping bar diameter, and in the present experiment is $20 \mathrm{~d}$, that is $2 / 3$ of the required length, to have a comparable average bond stress on the bars a factor of $2 / 3$ is multiplied to the applied load. Based on these two concepts the specimens were subjected to 10 times of

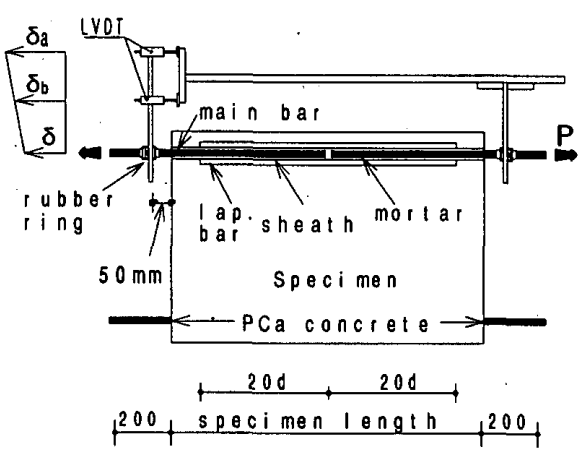

(a) Series 1

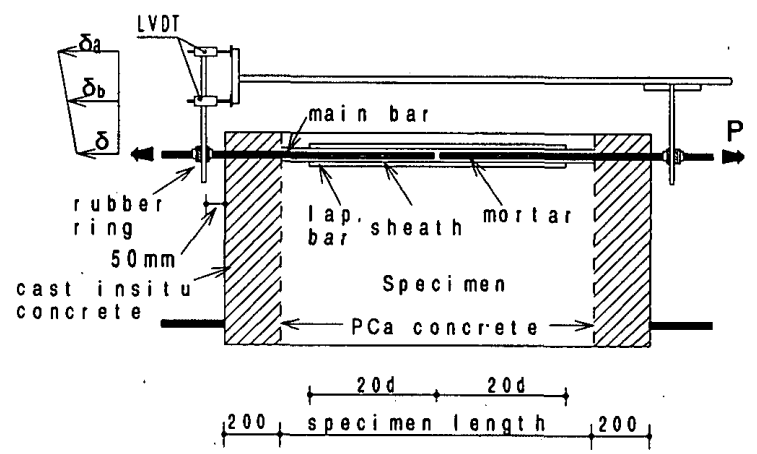

(b) Series 2 repeated loading at different magnitudes: $2 / 3$ of $1.1,1.3$, and 1.5 times the value of the specified yield strength of the main bar. In each case, after 10 cycles of repeated loads of the same magnitude, the maximum loads were obtained. Similar to that in the monotonic loading, the bottom bars yielded before bond failure while the top bars failed in bond before the bars yielded.

The following testing pattern was adopted for two specimens with the same parameter: first the top bar was tested until the specimen was close to failure. After which, the bottom bar was tested until it failed. The bottom bar of the second specimen was

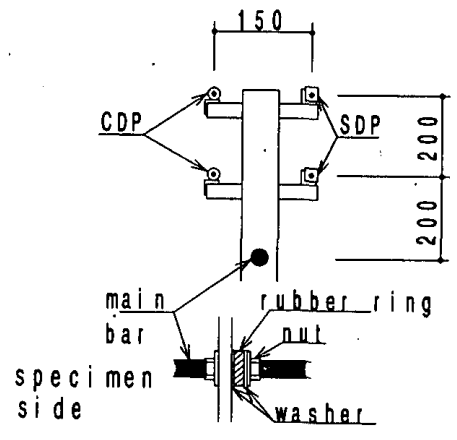

(c) Measuring devices
Fig. 7 Test apparatus tested until the load was close to the maximum load, after which, the top bar was tested until failure.

As it is mentioned in the failure pattern, no influence of the first loading was observed in the results of the second loading. Therefore, the order of loading is neglected later in the discussion of the test results. 


\section{Failure Pattern and Load-Displacement Relationship} 4.1 Failure pattern

The main bar, grouted mortar, and sheath behaved as a unit and all the top bars failed in bond around the sheath surface. The bottom bars also failed in bond around the sheath surface after the yielding of main bars.

The typical crack patterns are presented in Figs. 8 (a) and (b). Figure 8(a) shows the crack pattern obtained for Specimen PS20, with a lug height of $2 \mathrm{~mm}$. Figure 8(b) shows the crack pattern of the specimen AA-1. First transverse cracks appeared at $1 / 3$ the specimen length at the average load of 5 tonf. The first cracking loads for
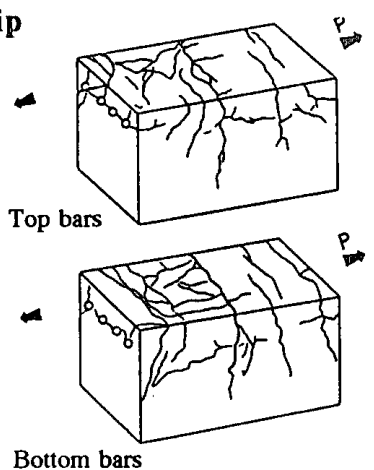

(a) Specimen PS20

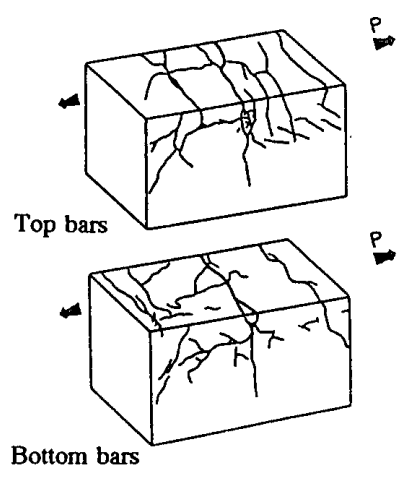

(b) Specimen AA-1

Fig. 8 Typical crack patterns

bars. As the load increases, transverse cracks developed at the center and at the longitudinal direction at both ends. Cracks spread with the increment of the load and before the maximum load a concentration of cracks at the corners was observed. The specimens with repeated load have a similar crack pattern to the specimens with monotonic loading.

For the specimens with 2-D10 as lateral reinforcement, just before failure a transverse crack appeared at the end of the lapping length, and the failure pattern was due to the splitting of the side bars. During the testing of the top bars, the specimens with lateral reinforcement of 4-D16 were broken at the midlength of the specimen (where the main bars abutted), with fewer number of cracks than in the other cases.

For the specimens where the cover concrete was studied, an increase in the number of cracks with the decrease of the cover concrete was observed. Specimens with cover concrete of $30 \mathrm{~mm}$ had a similar crack pattern to that with cover concrete of $40 \mathrm{~mm}$, except that the transverse cracks were distributed at $1 / 4$ of the specimen length. No large differences of the crack patterns between the top and bottom bars were observed, except that in case of the bottom bars, the crack width at the center became larger.

In the second series, specimens with splice types A and B showed a similar crack pattern to those specimens of the first series, as shown in Fig. 8(b). Cracks appeared first at 1/3 of the specimen length, spreading with the increment of the load. At the last stages, longitudinal cracks appeared at the upper face and inclined cracks (in the 45 degree direction) appeared at the lateral faces.

In splice types $C$ and $D$ (with only one lapping bar) less number of cracks were observed at the upper face, with similar pattern at the lateral faces to those specimens with splice types $A$ and $B$. Splice types $E$ and $F$, showed a similar pattern with those splice types A, B and C, D, respectively, with the only difference that at the upper face only three cracks were visible: one at the center and the other two at the lapping bar ends. This characteristic was also observed in specimens with splice type $G$.

4.2 Load-displacement relationship

Load-displacement relationships for some cases are presented in Figs. 9 and 10. In these figures the symbol " $\mathrm{x}$ " represents the point where the specimen reaches the maximum load. In general, the specimens presented almost the same load-displacement curves. Concerning to the stiffness, the specimens with two lapping bars presented higher stiffness than the specimens with one lapping bar for both the top and bottom bars. Specimens with bars at eccentric position inside the sheath have almost the same stiffness than the specimens with bars at the center of sheaths.

\section{Ultimate Joinit Strength}

Relations for all test specimens between main bar stress, average bond stresses (of main bar, sheath and lapping bars), and the variation of each parameter at the maximum loads are illustrated in the following sections. These bond stresses were obtained by converting applied maximum forces using Eq. (1). Also, bond splitting strength calculated using the formulas proposed by Fujii-Morita [6] Eq. (2), Orangun-Jirsa-Breen [7] Eq. (3) and Jimenez White-Gergely [8] Eq. (4) are plotted for every case. Equation (2) was derived for continuous bars from the bond splitting failure, 
while Equations (3) and (4) were derived for bars with lapping splices.

After the lower bars yielded, bond failure took place, however because it was not in the main bar surface, but at the exterior surface of the sheaths, it was assumed to have not a great influence on the bond strength of the spliced bars.

During the pullout test, a horizontal crack, termed a "side split failure" developed through the level of the bars. The calculation of the bond strength is therefore based on the following failure lines for the different splice types, as Fig. 11 shows. For splice types A and B, the "side splice failure" was observed along the sheath axis, in which case, the diameter of the sheath is considered instead of the diameter of main bars for the calculation, as shown in Fig. 11(a).

For the splice types $C$ and $D$, since the lapping bar has the same dimension as the main bar the failure line is formed along the axes of the lapping bars, and the diameter of the lapping bar is considered, as shown in Fig. 11(b). In this case the bond strength at the sheath is smaller than that
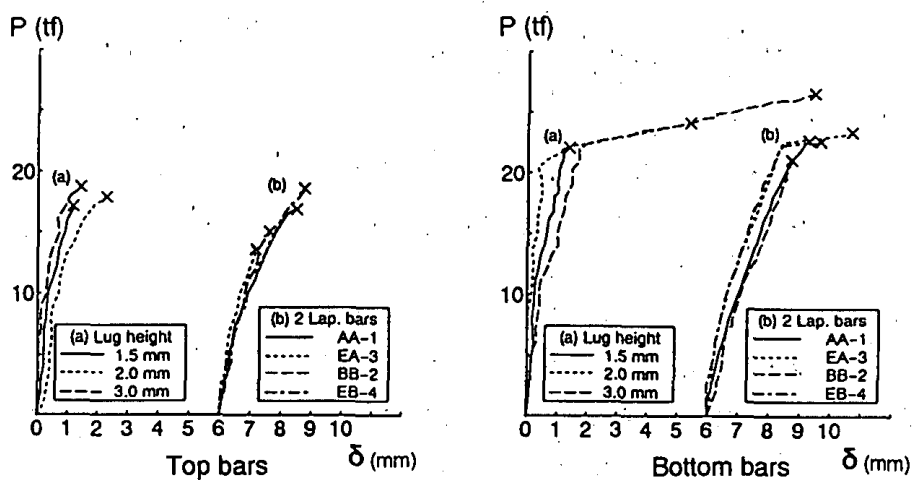

Fig. 9 P- $\delta$ relationships under monotonic loading
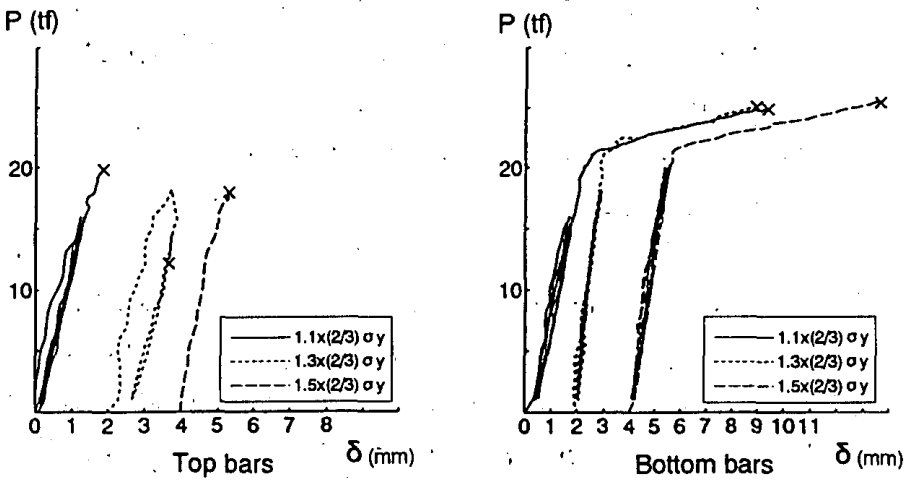

Fig. 10 P- $\delta$ relationships under repeated loading at the lapping bars. However, if this bond strength is multiplied by the perimeter and the lapped length to obtain the joint strength, the joint strength obtained using the perimeter of the lapping bar is smaller than that using the perimeter of the sheath. The failure line therefore occurs at the level of the lapping bar and not at the level of the sheath.

In the second series, since the concrete blocks were cast at both sides, it was difficult to observe clearly the position of the failure lines during the experiment.

For splice type $\mathrm{E}$, the failure line is formed along the axes of the main bars and the axes of one of the lapping bars as shown in

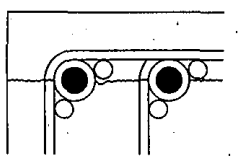

(a) Splice type A and B

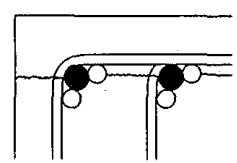

(c) Splice type E

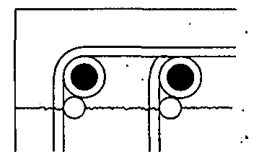

(b) Splice type $C$ and $D$

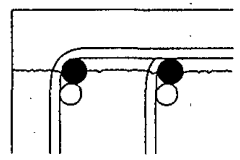

(d) Splice type F and G

Fig. 11 Failure lines for calculation Fig. 11(c). The diameter of the main bar is considered for calculating the joint strength.

In the case of splice types $F$ and $G$, the formation of the failure line is along the axes of the main bars. Thus its diameter is considered for the calculation of the bond strength, as shown in Fig. 11 (d).

Under these observations and hypotheses, the bond failure strengths were obtained at the perimeter of sheaths for splice types $A$ and $B$, at the perimeter of lapping bars for splice types $C$ and $D$, and at the perimeter of the main bar for splice types $\mathrm{E}, \mathrm{F}$ and $\mathrm{G}$.

$$
\begin{aligned}
& \tau_{\exp }=\frac{P \max }{l s \phi} \ldots \ldots \ldots \ldots \ldots \ldots \ldots \ldots \ldots \ldots \ldots \ldots \ldots \ldots \ldots \ldots \ldots \ldots \\
& \tau_{c m}=\left(0.307 b_{i}+0.427+24.9 \frac{k \cdot \ldots}{s N_{t} d_{b}}\right) \sqrt{\sigma_{B}}
\end{aligned}
$$

multiplied by 1.22 for bottom bars,

$$
\tau_{c o j}=\left(1.2+3 \frac{\dot{c}}{d_{b}}+50 \frac{d_{b}}{l s}+\frac{A_{w} w^{\sigma_{y}}}{35.2 N_{t} s d_{b}}\right) 0.265 \sqrt{\sigma_{B}}
$$

divided by 1.3 for top bars, 


$$
\tau_{c j i}=\frac{1}{4}\left(\frac{c \sqrt{\sigma_{B}}}{0.105 d_{b}+0.0017 l s}+0.573 \rho_{v} f_{y t}\right)
$$

Where:

Pmax: maximum force in the main bar $(\mathrm{kgf})$;

$\phi$ : perimeter of main bar or sheath $(\mathrm{cm})$;

$1_{s}$ : lapped length $(\mathrm{cm})$;

$b_{i}$ : parameter for the failure of concrete;

$k$ : parameter of the lateral reinforcement, $k=1$ for side splitting failure;

$\mathrm{A}_{\mathrm{st}}=\mathrm{A}_{\mathrm{W}}$ : area of lateral reinforcement $\left(\mathrm{cm}^{2}\right)$;

$\mathrm{N}_{\mathrm{t}}$ : total number of main bars (two jointed bars inside one sheath are referred as one main bar);

$\mathrm{d}_{\mathrm{b}}$ : diameter of main bar or sheath $(\mathrm{cm})$;

$f_{y t}={ }_{w} \sigma_{y}$ : yielding strength of lateral reinforcement $\left(\mathrm{kgf} / \mathrm{cm}^{2}\right)$;

c: half clear spacing between bars or half available concrete width per bar or splice resisting splitting in the failure plane $(\mathrm{cm})$;

$\sigma_{\mathrm{B}}: \quad$ concrete cylinder strength $\left(\mathrm{kgf} / \mathrm{cm}^{2}\right)$;

$\rho_{\mathrm{v}}$ : lateral reinforcement ratio.

The experimental bond strength $\tau_{\exp }$ and the calculated bond strength $\left(\tau_{\mathrm{cm}}, \tau_{\mathrm{coj}}, \tau_{\mathrm{cjij}}\right)$ are compared in Figs. 12, 13, and 14 for both series of experiments. The test results do not agree with the bond strengths $\tau_{\mathrm{cm}}$ calculated by the Fujii-Morita's Eq. Most of the test results agree well with the bond strengths $\tau_{\text {coj }}$ calculated by the Orangun-JirsaBreen's Eq. The calculated bond strength, however do not coincide with some of the test results from the bottom bars that yielded before the bond failure. The predominant factors in Eq. (4), $\tau_{\mathrm{cji}}$ proposed by Jimenez-White-Gergely, are the compressive strength and the thickness of cover concrete, while the amount of lateral reinforcement has a small influence. Therefore, with almost the same concrete strength and thickness of cover concrete, the correlation

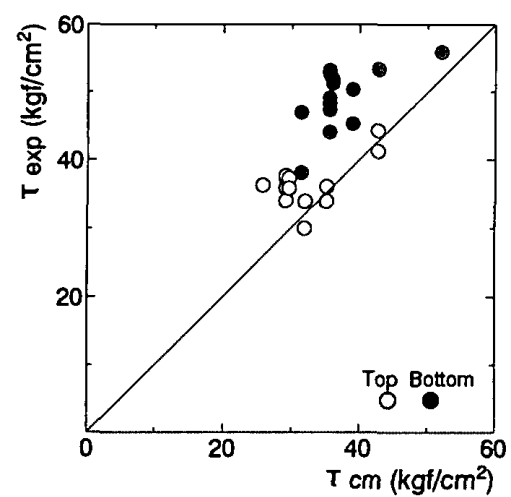

(a) Series 1

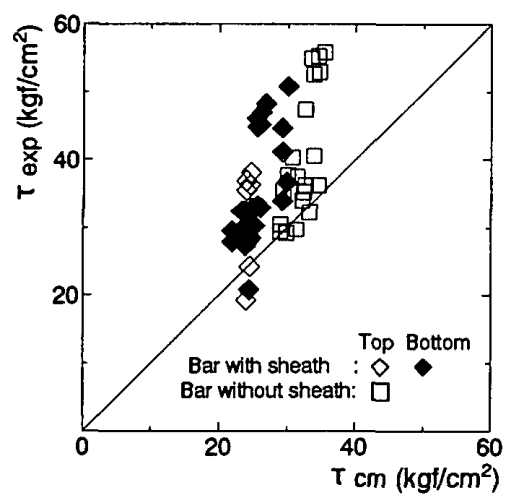

(b) Series 2

Fig 12 Comparison by FujiiMorita's Equation

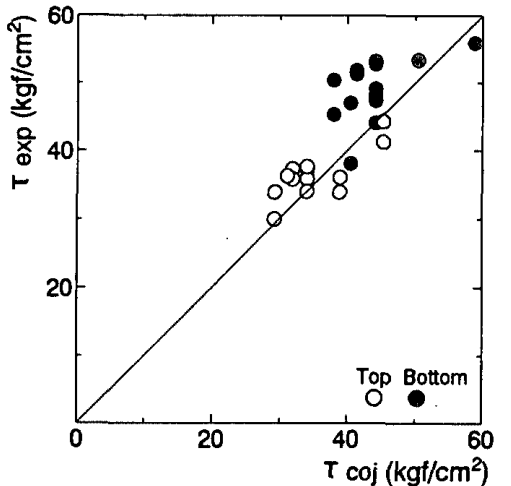

(a) Series 1

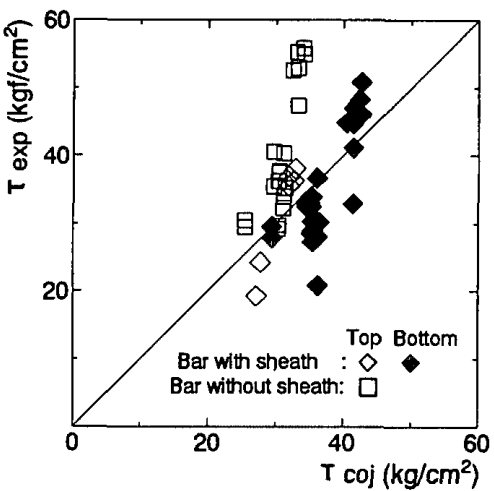

(b) Series 2

Fig. 13 Comparison by OrangunJirsa-Breen Equation

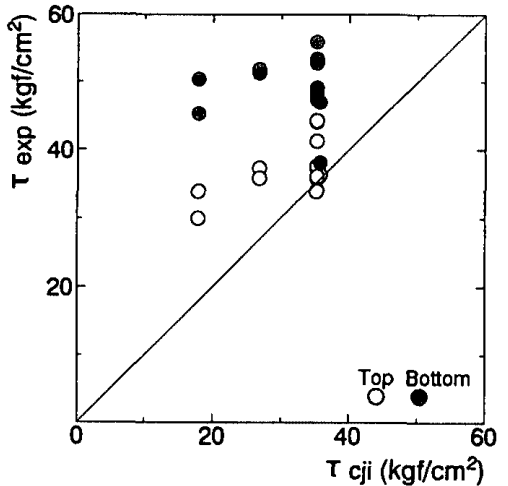

(a) Series 1

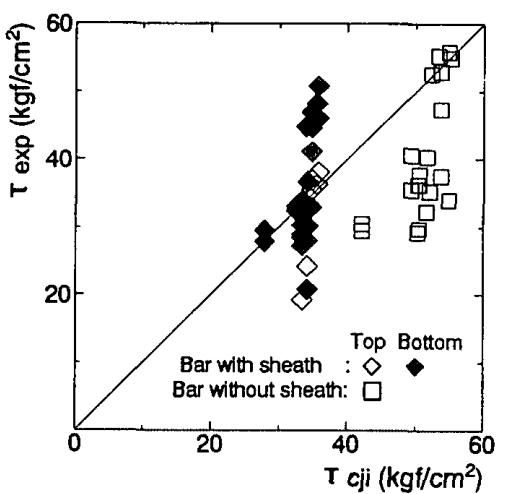

(b) Series 2

Fig. 14 Comparison by JimenezWhite-Gergely Equation 
appears as a almost vertical line for the test results of the bar joints with and without sheaths.

Figure 15 shows the relationship between the maximum strength of the top and bottom bars in the first and in the second series. The maximum loads on the bottom bars in the first series and in the second series were on the average 1.37 and 1.35 times greater than those on top bars, respectively. The specimens with splice types $E, F$, and $G$ (specimens without sheaths) are not considered in the calculation. It is also noted that the maximum loads for the bottom bars were obtained after the bar yielded.

5.1 Influence of the lug height of the sheath

Figure 16 shows the relation between the lug height and the parameters such as the tensile stresses on the main bar, average bond stresses on the main bar, on the sheath, and on the lapping bar at the maximum loads. The test results of the specimens with two lapping bar joint type are presented in Figs. 16, 17, 18, and 19.

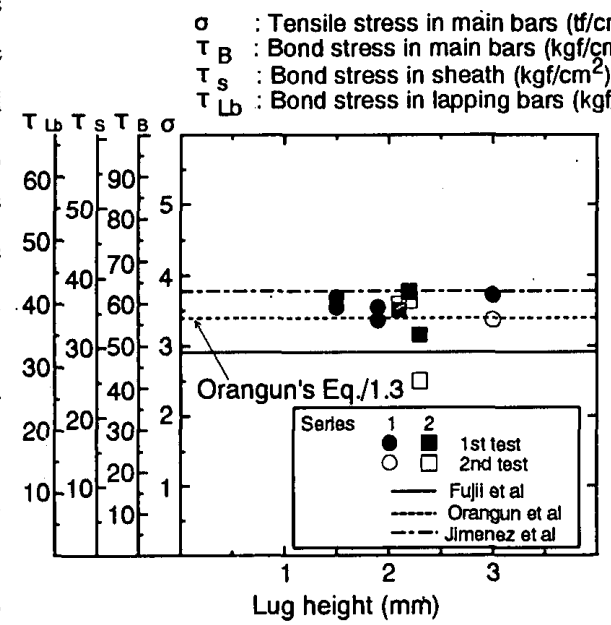

(a) Top bars

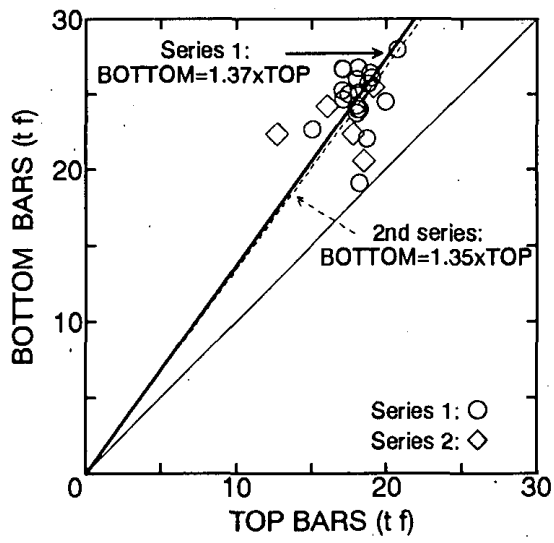

Fig. 15 Differences on the bond strength between top and bottom bars

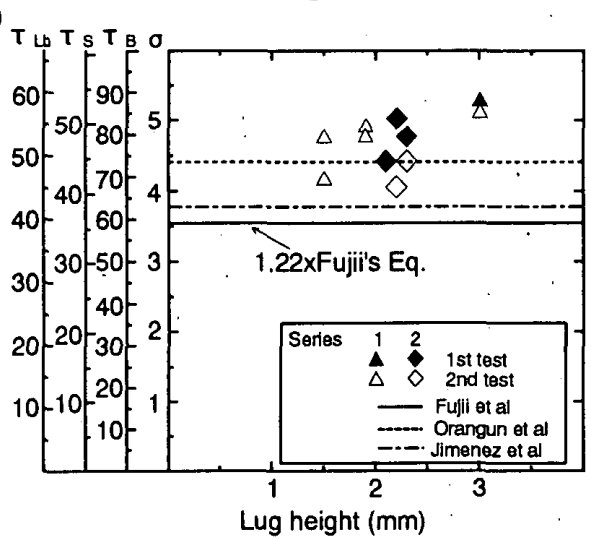

(b) Bottom bars [5], the bond strength on a constant bar diameter

Fig. 16 Influence of the lug height of sheath decreases when the ratio of the lug distance to the lug height increases. In this test, the distance between lugs of the sheath is kept constant $(28 \mathrm{~mm})$ and only the lug height is varied. A slight increase in the bar stress of the bottom bars is observed when the height of the sheath lug is increased, while for the top bars, which failed in bond around the sheath surface, the main bar stresses remain almost constant. In this figure, the calculated values using the Orangun-Jirsa-Breen equation shows good agreement with the test results, while those calculated using the Fujii-Morita equation gives lower values. The results using the Jimenez-White-Gergely equation have a better agreement than those of the Fujii-Morita equation for the test results of top bars. Even though the height of the sheath lug is not considered in both equations (Orangun et. al and Jimenez et. al.), the Orangun-Jirsa-Breen equation fits well with the results of this experiment. 5.2 Influence of the thickness of the cover concrete

Figure 17 shows the relation between the lapping joint strengths and the thickness of cover concrete. In spite of an increase in the strength when the cover concrete is 20 and $30 \mathrm{~mm}$, there was a decrease in strength at 40-mm thickness. The reason why the test results are almost constant could be because all the bars of the specimens are confined laterally and they failed in the side split failure mode.

In this figure, there is a good agreement between the test results obtained for the top bars and those of Orangun-Jirsa-Breen's equation, but discrepancy was noted when compared to the test results obtained from the bottom bars. The calculated data using Fujii-Morita equation on the bottom bars agree well with the test results on the top bars. In this experiment, as predicted by the Fujii-Morita equation, side split bond failure was expected. This is the reason why the calculated values using Fujii-Morita equation remain almost constant in Fig. 17. The JimenezWhite-Gergely equation, in which the cover of concrete is a predominant parameter, gives closer values than the test results of the top bars, although some values are dispersed. For the bottom bars, this dispersion became prominent. 
5.3 Influence of the lateral reinforcement ratio

Figure 18 shows the relation between the joint strengths and the lateral reinforcement ratios. When the lateral reinforcement ratio is increased, considerable increase in the strength can be observed on the bottom bars, but slightly increase on the top bars.

The values obtained using Orangun-Jirsa-Breen's equation show a good agreement with both the top or bottom bar test results, while the calculated values for the top bars using Fujii-Morita equation also showed good agreement with the test results. The effect of the lateral reinforcement on the Jimenez-White-Gergely equation is minimal

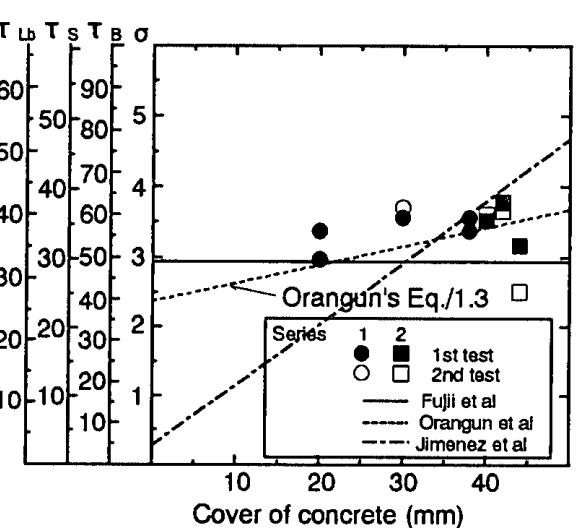

(a) Top bars

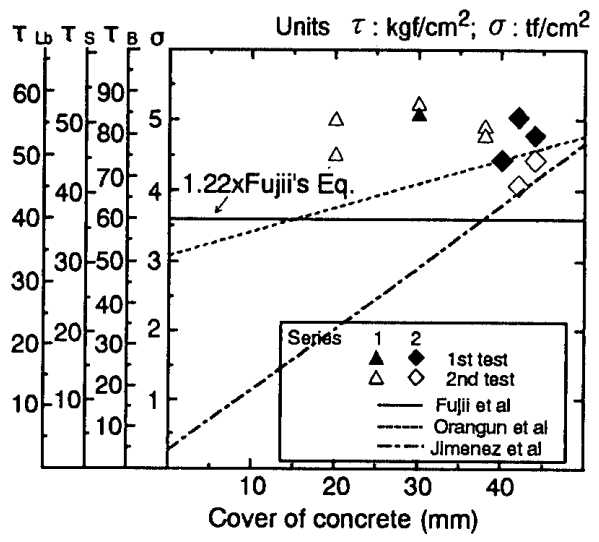

(b) Bottom bars

Fig. 17 Influence of the thickness of cover concrete

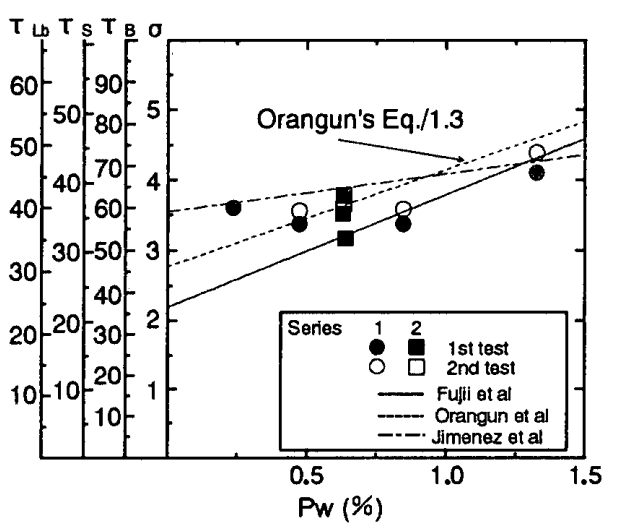

(a) Top bars

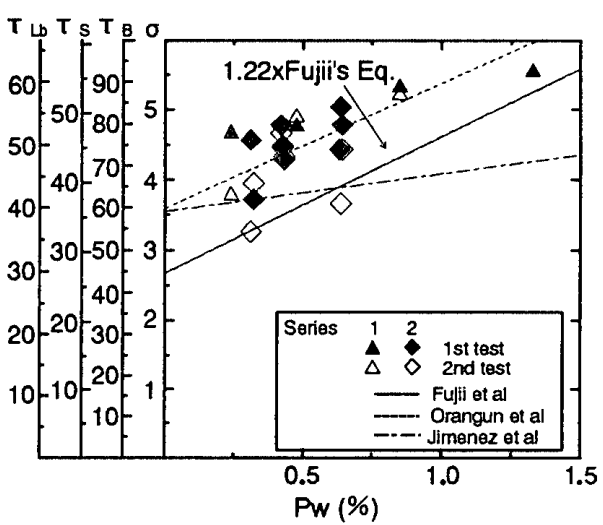

(b) Bottom bars

Fig.18 Influence of the lateral reinforcement ratio compared to its effect on the other two equations. For this reason the calculated values from this equation are plotted by a horizontal line. Using this equation, a good agreement with the test results of the top bars is recognized, however same tendency was not observed for the bottom bars.

\subsection{Influence of the loading history}

Figure 19 shows the relationship between the number of times the specimens were loaded and the factors such as the tensile stress on main bar, and the average bond strengths at the maximum loads. In this figure, the maximum load reached after ten cycles of loading were completed is represented by the head of the arrow.

After ten cycles of loading were completed, the bottom bars were pulled until the maximum loads were reached, but the

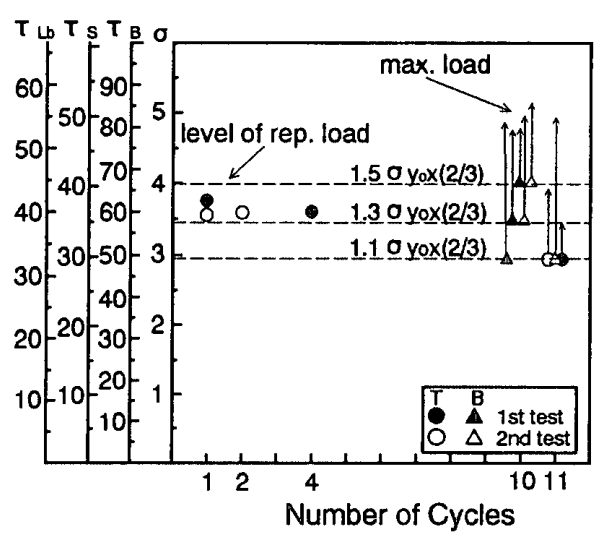

Fig. 19 Influence of the loading history specimens for the top bars were broken during the ten cycles of loading except the specimens tested at $1.1 \times(2 / 3)$ times the specified yield strength.

For the top bars, four specimens failed at approximately 18 tonf, which is about $1.3 \times(2 / 3)$ times the specified yield strength, after 1,2 and 4 cycles, respectively.

No difference among the results due to the variation of repeated loads was observed. Top and bottom bars showed a similar behavior to those under monotonic loading. Also, the maximum load obtained after ten cycles of loading were about the same as those under monotonic loading. 
5.5 Influence of the number of spliced bars

Figures 20 (a) and

(b) show the relation between the types of joint splices and the quantities such as the tensile stress on the main bar, and the average bond stresses on the main bar, on the sheath and on the lapping bar at maximum loads. The amount of lateral reinforcement ratio pw is not the

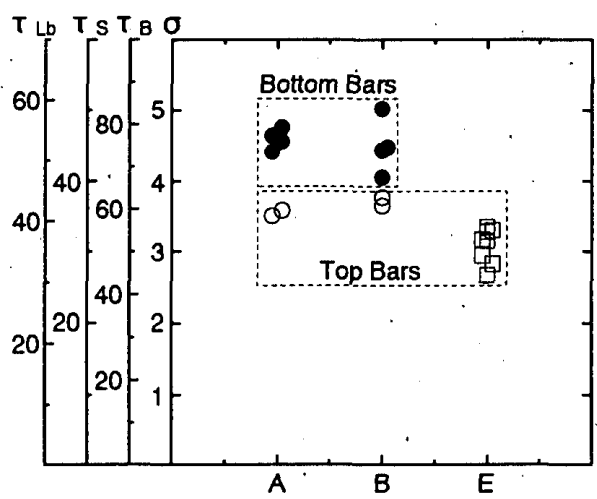

(a) Splices with two lapping bars

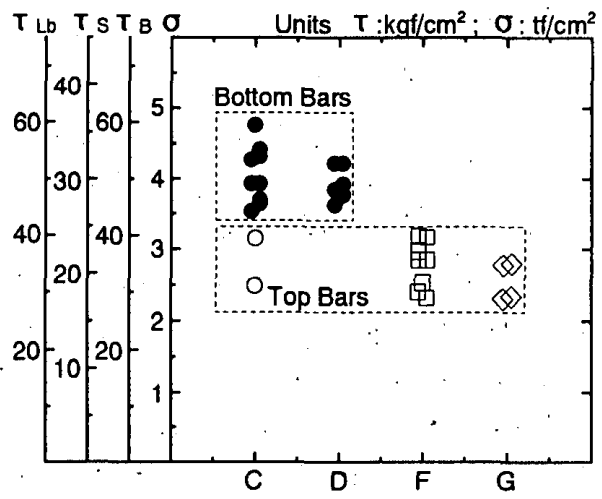

(b) Splices with one lapping bars

Fig. 20 Influence of the position of bar inside the sheath same, but also not so different. As it was summarized above (Section 5.3: Influence of the lateral reinforcement ratio), the contribution of $\mathrm{pw}$ is not large therefore a rough comparison can be possible. No large difference is observed between splice types $\mathrm{A}$ and $\mathrm{C}$, and also between splice types $\mathrm{B}$ and $\mathrm{D}$. Therefore, no remarkable influence of the number of lapping bars on the bar joint strength is recognized. However, because of the fewer number of the test specimens, this can not be strongly said.

5.6 Influence of the position of the bar inside the sheath

From Figs. 20 (a) and (b), no remarkable difference can be recognized between splice types A and B, and also between splice types $C$ and $D$. This means that the eccentricity of the bar from the sheath axis has no influence on the joint strength.

5.7 Influence of the sheath

Some slightly higher values of the strength of the top bar joints with sheaths (splice types A, B, and C) than those without sheaths (splice types E, F and G) are found in Figs. 20 (a) and (b).

\section{Conclusions}

The following conclusions were obtained after the study of the bar joint strength through pull out tests for a precast concrete method, where the precast member was produced using spiral sheaths lapped with one or two bars, with the main bars inserted and high strength mortar grouted in after.

1) The system composed by main bar-mortar-sheath behaved as a unit.

2) Under the same conditions the joint strength of the bottom bars was about $1.35-1.40$ times that of the top bars.

3) The bond strength was almost constant for the top bars.when the lug height was increased, but a slight increase for the bottom bars was observed.

4) The thickness of cover concrete had no remarkable effect on the strength of the bar joint which failed in the side split failure mode.

5) When the lateral reinforcement ratio was increased, the strengths of bottom bar joints increased considerable, while those of top bar joints increased slightly.

6) At repeated loading, ten cycles of loading had no remarkable influence on the joint strength.

7) The eccentricity of the bar from the sheath axis had no effect on the joint strength of spliced bars.

8) The splice joint with sheath had similar strength to the conventional lapping joint cast in situ concrete.

9). The Orangun-Jirsa-Breen equation can be used to estimate the bond strength of the proposed bar joint with good accuracy if the diameter of the sheath is used instead of the diameter of main bars.

10) The main bar-mortar-sheath-lapping bar system proves to be adequate in transferring the tensile stress of each main bar through the surrounding concrete. 


\section{References}

1) Architectural Institute of Japan, "AIJ Standard for Calculation of Reinforced Concrete Structures"

2) Imai, H.; Yamaguchi, T.; Yanez, R., "Bond Performance of a Lapping Joint Developed for Precast Concrete Columns", Proceedings of The Japan Concrete Institute, Vol. 13, No 2, 1991, pp.1063-1068.

3) Yanez, R.; Yamaguchi, T.; Hibino K.; Imai, H., "An Experimental Study on the Strength of a Proposed Bar Joint for Precast Concrete Columns", Proceedings of The Japan Concrete Institute, Vol. 14, No 2, 1992, pp. 999-1004.

4) Juan Jose Castro, Teruaki Yamaguchi, Hiroshi Imai, "Seismic Performance of Precast Concrete Beam-Column Joints", Journal of Structural and Construction Engineering, Transactions of AIJ. No 455, January 1994, pp. 113-126.

5) Lutz, L. A.; Gergely, P., "Mechanics of Bond and Slip of Deformed Bars in Concrete", ACI Journal, Vol. 64, No. 11, November 1967, pp. 711-721.

6) Fujii, S; Morita, S., "Splitting Bond Capacity of Deformed Bars (Part 2), A Proposed Ultimate Strength Equation for Splitting Bond Failure (in Japanese)", Transactions of AIJ, No. 324, Feb. 983, pp. 45-53.

7) Orangun, C.O.; Jirsa, J.O.; Breen, J.E., "A Reevaluation of Test Data on Development Length and Splices", ACI Journal, Vol. 74, March, 1977, pp. 114-122.

8) Jimenez, R.; White, N.; Gergely, P., "Bond and Dowel Capacities of Reinforced Concrete", ACI Journal, Proceedings Vol. 76, No. 1, January 1979, pp. 73-92.

9) Paulay, T., "Lapped Splices in Earthquake-Resisting Columns", ACI JOURNAL, Proceedings Vol. 79, No. 6, NovemberDecember 1982, pp. 458-469.

\section{和文要約}

\section{1. はじめに}

プレキャストコンクリート（以下、PCa）工法では部 材接合の方法と位置は構造物の挙動に大きな影響を与え る。

初期のラーメン式PCa工法では、図一1(a)に示すよう に設計応力の小さい柱やはりの中央部で部材を接合して いた。この工法では、部材形状が複雑で、製作と運搬が 困難であった。

次の段階では、柱や梁の単材をPCa部材にし、図一 1(b)に示すように設計応力の大きい柱梁接合部付近で接 合するようになった。この方式はPCa部材の製作や運搬 の点で有利であるが、主に梁下端筋の配筋方法に関して 構造的な問題が多い。

従来のPCa工法では、主筋がPCa部材内に打ち込まれ ていたので、主筋とPCa部材の各接合位置が同じ位置に なっていた。このため、上述したようにPCa部材の生産 性能と骨組の構造性能は両立しにくかった。

ここで提案するPCa工法では、PCa部材には原則とし て主筋を入れないので、主筋とPCa部材の各接合位置を 同じにする必要がなく、図ー1(c)及び図ー2に示すよう にPCa部材は柱や梁の単材であるが、主筋はPCa部材の 中央部分（部材両端の降伏ヒンジ領域を除いた部分）で 設合され、柱梁接合部では通し配筋となっている。

このPCa工法では、柱や梁の主筋はPCa 部材に配置さ
れたスパイラルシース内に配筋される。接合する両主筋 の端部は、設計応力の小さい部材の中央部分で、重ね継 手によって接合されている。重ね継手は、モルタルとシ 一スを介し、シースの外側に配置された添筋（原則とし て、柱では2本、梁では1本）を利用して行われる。PCa 部材を製作する時には、主筋の位置にシースと添え筋を 配してコンクリートを打設する。現場では PCa部材の シース内に主筋を挿入し、高強度モルタルを圧入する。

本研究の目的は、シースの山高さ、かぶり厚さ、横補 強筋量、継手形式、及び加力方法が、本重ね継手の引張 強度に与える影響を調べることである。

\section{2. 試験体}

試験体数は、48体であり、2つのシリーズに分けて両 引実験が行われた。図一3と表一1に示すように、シリー ズ1では、同一試験体を各2体、11種類、計22体が製作さ れた。PS15、PH410、PL40は同じ標準試験体である。 標準試験体では、断面は600x600mmで、長さが900mm で、上下に各4本の主筋がある。8本のシース（内径 $42 \mathrm{~mm}$ 、山高さ $2.0 \mathrm{~mm}$ ）を囲むように、溶接閉鎖型せん 断補強筋を100mm間隔で配筋して、2本のD19(SD390)の 添筋を各シースに接するように配筋した。重ね長さは 20d（d:添筋径）であり、添笳の全長は40dで、760mmで ある。

上記の標準試験体を基に、シース形状、かぶり厚さ、 横補強筋量を変化させて他の試験体を製作した。シース 
の山高さは1.5、2.0、3.0mmの3種類とした。横補強筋に は、D10、D13、または、D16（いずれもSD295Aで @100）の鉄筋を使用し、中子笳のない試験体も含め4種 類を製作した。かぶり厚さは、20、30、40mmの3種類 とした。

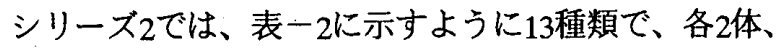
合計26体が製作された。図ー4に断面の例を示す。主な 変動因子は継手形式、横補強筋の量と間隔である。なお 継手形式は図ー5に示す7種類で、形式A〜Dがシースを 利用した重ね継手であり、形式E〜Gは場所打ち工法で の重ね継手である。形式A、Bは2本添筋で、形式C、D は1本添筋である。形式B、Dでは、梁を想定し、主筋が シース内で偏心している。

主筋はD25のネジ節鉄笳であり、添筋は2-D19または 1-D25の異形鉄笳である。重ね長さは20d（dは添筋径） であり、添筋の全長は40dである。シースの形状はシリー ズ1の標準試験体のもと同じであり、内径は $42 \mathrm{~mm}$ 、山

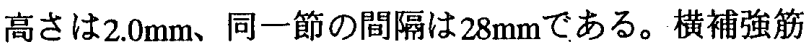
(D10、SD290A)には、溶接閉鎖型鉄筋を組み合わせて用 いた。

両シリーズとも、まず横補強筋と主筋またはシースと 添筋で鉄筋籠を作り、シースまたは主筋を水平にしてコ ンクリートを打設し、PCa部材を製作する。シリーズ1 では、シースを鉛直にしてシースの上下入ロより2本の 主筋D25(SD390)のネジ節鉄筋をシースの中央で向かい 合うように㨂入し、シースの下の入り口をふさいだ後、 シース内に高強度モルタルを上より注入した。シリーズ 2では、シースを水平にしてシースの中央部で主筋が向 かい合うように主筋を挿入した後、シースの両開口部を シールして、試験体の両側にコンクリートを打設する。 これは、実際の梁の場合では、柱梁接合部の場所打ちコ ンクリートに相当する。最後にパイプを用いて、シース 内に高強度モルタルを圧入する。

表ー3、4、および5にそれぞれ鉄笳、コンクリート、お よび充填モルタルの材料試験結果を示す。コンクリート とモルタルの設計圧縮強度はそれぞれ300 $\mathrm{kgf} / \mathrm{cm}^{2} 、$ $600 \mathrm{kgf} / \mathrm{cm}^{2}$ である。コンクリートの圧縮強度は継手の両 引き試験時のものであり、モルタルの圧縮強度は両引き 試験より少し前に試験した值である。なお各值は3つの 平均値である。 DF-8のみ誤って圧縮強度 $200 \mathrm{kgf} / \mathrm{cm}^{2}$ の コンクリートが打設され、他より小さい。

\section{3. 実験方法}

加力方法は試験体の両側にある油圧ジャッキにより各 鉄筋に等しい引張力を与える両引き加力であり、大部分 は単調加力である。図一6に示すように、両側の鉄筋に 測定冶具をゴムリングを介して固定し、重る継手をされ た両側の主筋間の2箅所の变形を測定し、外挿補間によ
り鉄筋位置での变形を求めた。

絽り返し試験では、主筋1本あたり上限荷重をPtonf、 下限荷重を1tonfとする10サイク程度の絽り返し加力を行 った後、最終的に破壊させた。上限荷重Pには、16tonf、 18tonf、及び20tonfの3種類を設定した。これは、それぞ れ主筋の規格降伏点の $1.1 、 1.3 、 1.5$ 倍の $2 / 3$ 倍に相当す る。係数2/3は、重和長さが実験では20d（d：添筋の径） であるが、実際の設計では30d以上を想定しているため である。

同一試験体2体のうち、原則的に1体は先に上端筋を試 験し次に下端筋の順で、他の1体は先に下端筋を、次に 上端筋の順で試験した。

\section{4. ひび割れ状況と荷重一変形曲線}

主筋、グラウトモルタル、シースは一体として挙動し た。上端筋は、主筋が降伏する前に、また、下端筋は、 降伏後に、シースの表面で付着割裂破壊をした。典型的 なひび割れ状況を、図ー8に示す。まず、平均5tonで、 試験体長の $1 / 3 に$ 主筋に垂直方向のひび割れが発生した。 下端筋の初期ひび割れ荷重は、上端筋の約1.3倍であっ た。

2-D10の横補強筇を用いた試験体は、上下段筋とも明 らかに、主筋に沿う付着割裂破壊によるものであった。 4-D16の横補強筋を用いた上端筋の試験体は、中央部

（主筋端が向かい合っている継手部分）で添筋が伸びて 破壊した。

コンクリートのかぶり厚さを変動因子とした試験体で は、かぶり厚さが小さくなると、ひび割れ数は増加した。 シリーズ2の継手形式A、B、C、.及びDは、シリーズ1 のものと同侎なひび割れ状況を示した。

継手形式EとFのひび割れ状況は、上面に3本のひび 割れがだけ見られたという違いだけで、それぞれ継手形 式A、BとC、Dと同様であった。その3本のひび割れは、 中央に1本と添筋の両端の2本である。この特性は、継手 形式Gの試験体にも見られた。

図ー9と10に荷重一变形曲線の例を示す。この図で、 $\mathrm{x}$ 印は最大荷重に到達した点である。上端筋と下端筋ごと に似たような荷重一变形曲線を示した。

\section{5. 実験結果}

最大荷重時の主筋の引張応力、及び主筋、シース、添 筋の平均付着応力と各影響因子の量との関係が、各節ご とに図で表されている。既往の付着割裂強度算定式であ る藤井・森田式（式2）、及び重ね継手の強度算定式で ある Orangun- Jirsa-Breen式（式 3、以下 OJB式）、 Jimenez-White-Gergely式（式4、以下JWG式）による計 算値と実験值の比較を図一12、13及び14に示す。

計算では、図ー11に示すような観測された主要なひび 
割れ線に基づいて、鉄筋のあき、および主筋径は次のよ うに決めた。継手形式A、Bの鉄筋のあきにはシース間 を、主筋径にはシース径を用いる。継手形式C,Dの鉄筋 のあきには添筋間を、主筋径には添筋径を用いる。これ は継手形式C、Dではシース周りの付着割裂強度は添笳 周りより小さくなるが、周長と重ね長さを掛け合わせた 継手強度は添筋周りの方が小さくなるので、この位置で 割裂面が発生する。シリーズ2では、試験部分の両端に あるコンクリートのブロックのため、ひび割れの位置は、 はっきりと区別できなかった。継手形式Eの鉄筋のあき には主筋と添筋を一組とした時の内法距離を用いる。実 験値は継手形式A、Bではシース周り、継手形式C、Dで

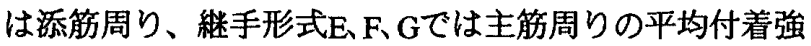
度である。

下端筋は最大耐力時には降伏していたが、主筋の外周 でなく、シースの外周で付着割裂したので、主筋の降伏 がシースの付着強度に与える影響は小さいものと思われ る。

困ー12に示すように、藤井・森田式は全体として良く 実駼結果と一致するが、下端筋について誤差が大きい。 圀一13に示すように、OJB式の計算値は、上端筋と下端 筋とも実験値と一致し、特に下端笳の誤差は小さい。図 一15に下端筋と上端筋の継手強度を比較する。シリーズ 1と2の結果は平均として同じ値で、下端筋の継手強度は 上端筋の約1.35〜1.40倍である。

図一16、17及び18には2本添筋だけの実験結果が示され ている。

5.1 シースの山高さの影響

図ー16に示すように、下端筋では、シースの山が高く なると最大荷重は大きくなるが、上端筋の付着強度は山 高さに関係なく、一定である。OJB式による計算値は藤 井・森田式より良く実験結果と一致する。計算值が山高 さにかかわず一定であるのは、既往の計算式では山高さ の影響が考慮されていないためである。

\section{2 かぶり厚さの影響}

図ー17に示すように、かぶり厚さに関係なくほぼ同じ 強度を示す。これは、全鉄筋が横補強筋によって、拘束 され、かつ、サイドスプリット型の付着割裂破壊をした ためと思われる。かぶり厚さ40mmのものに強度の低下 が実験で認められるが、ばらつきの範囲内と考えられる。 藤井・森田式の計算值が、一定值となるのは、サイドス ップリット型と判定されるためである。

\section{3 横補強筋量の影響}

図ー18に示すように、下端筋の継手強度は、横補強筋 比が大きくなるに従い、大きくなっている。上端筋にお いては、同様の傾向がはっきりとは認められない。OJB 式が良く実験結果と一致する。上端筋については、藤井 ・森田式も良く合う。

\section{4 繰り返し試験の影響}

図一19では、矢印の頭は繰り返し後の最大応力を示す。 上端筋は、主筋の繰り返し応力を $1.1 \sigma_{y \circ} \cdot 2 / 3$ に設定す ると10回の絽り返し加力に耐えるが、 $1.3 \sigma_{y_{0}} \cdot 2 / 3$ に設 定した場合、繰り返し回数は2 4回程度である。そして、 $1.5 \sigma_{y_{0}} \cdot 2 / 3 て ゙ は 、 1$ 回しか加力できなかった。下端筋 は、全ては10回の繰り返し加力に耐え、その後の強度は ほぼ単調加力のものに近かった。以上より、10回程度の 繰り返し加力では、最大耐力には大きな影響を与えない と考えられる。

\section{5 添筋数の影䈉}

図一20に示すように、シースのある下端筋では、継手 形式AとC及びBとDの結果には、大きな差がない。この ことより、添筋数が重称継手強度に与える影響は小さい。 5.6 シース内の主笳の偏心の影響

図一20では、横補強筋量が各試験体で少し異なってい るが、下端筋と上端筋ごとにほぼ同じ值にまとまってお り、A,B間及びC,D間には強度差がないので、シース内 の主筋の偏心は最大強度に影響しないと判断できる。

\section{7 シースの有無の影響}

図一20において、シースを用いた重ね継手（形式A、B、

C）は、従来の場所打ち工法による重的継手（形式E、F、

G）と、ほぼ同等以上の強度を持つことが認められる。

\section{6. まとめ}

主筋位置にシースと添筋を置いたPCa部材に、主筋を 挿入して高強度モルタルを任入するPCa工法の重ね継手 の引張強度は次のようにまとめられる。

1）主筋・モルタル・シースは一体として挙動した。

2）同じ条件の場合、下端笳の継手強度は上端筋の約 1.35〜1.40倍であった。

3）シースの山が高くなると下端筋の継手強度は大きく なるが、上端筋の場合はその影響が小さかった。

4）サイドスプリット型で、付着割裂したので、かぶり 厚さが継手强度に与える影響は小さかった。

5）下端笳では、横補強笳比が大きくなるに従い、継手 強度が大きくなった。上端筋では、その影響が小さ かった。

6）10回程度の繰り返し加力では、重ね継手強度には影 響を与えなかった。

7）シース内での主筋の偏心は継手強度に影響しなかっ た。

8）シースを用いた重ね継手は、従来の場所打ち工法に よる重ね継手と同じような引張強度を持った。

9) シース径を鉄筋径とみなして、OJBの重ね継手強度式 で本継手工法の強度を良く計算できる。

10）主筋・モルタル・シース・及び添筋による重ね継手 は、主筋の応力を他方の主筋へ適切に伝達できる。 (1994年 7 月 4 日原稿受理, 1994年12月22日採用決定) 